\title{
A Planned City Comes of Age: Rethinking Ciudad Guayana Today
}

\author{
Clara Irazábal \\ School of Policy, Planning and Development, University of Southern California
}

\begin{abstract}
In the 1960s, planners from MIT and Harvard, supported by an interdisciplinary group, were invited by the Venezuelan government to interact with national professionals to create a "growth pole" in the southern part of the country. A city named Ciudad Guayana was founded in 1961. The planning process that followed was extensively documented by this group of American scholars and their counterparts in Venezuela. Probably the strongest critique to this process has been presented by the American anthropologist Lisa Peattie who, in Planning: Retbinking Ciudad Guayana (1987), unveils the unbridgeable gap between the "platonic city" designed by the planners based on the development paradigm, and the "aristotelian city" that unfolded in reality. This study investigates national and local politics in the planning, decision-making, and building practices of the city, and their definite imprint on its urban form and quality of life. Emphasis is placed on the last 15 years, and particularly the period since 1999, when Hugo Chávez Frías assumed the presidency of Venezuela.
\end{abstract}

Keywords: Ciudad Guayana, urban planning, development

\section{Resumen}

En la década de 1960, un grupo interdisciplinario de planificadores del MIT y Harvard fueron invitados por el gobierno nacional Venezolano a trabajar recíprocamente con profesionales Venezolanos para crear un "polo de desarrollo" en la parte sur del país. Como consecuencia de este proceso, se (re)fundó una ciudad en 1961 llamada Ciudad Guayana. El proceso de planificación que siguió fue documentado extensivamente por este grupo de expertos Estadounidenses y sus contrapartes en Venezuela. Probablemente la crítica más fuerte a este proceso, presentada por la antropóloga estadounidense Lisa Peattie en Planning: Retbinking Ciudad Guayana (1987), revela la significativa brecha entre la "ciudad Platónica" diseñada por los proyectistas con base en el paradigma de "desarrollo", y la "ciudad Aristotélica" que se desplegó en la realidad. Este artículo investiga la política local y nacional en la toma de decisiones y las prácticas de desarrollo urbano en Ciudad Guayana, y su impacto en la forma urbana y en la calidad de vida en la ciudad. El énfasis se pone en los últimos 15 años, y particularmente desde 1999, cuando Hugo Chávez Frías asumió la presidencia de Venezuela.

Palabras claves: Ciudad Guayana, planificación urbana, desarrollo

"There are many ways to think of a city. A city can be though of as built form-buildings, open spaces, passages, barriers. It can be thought of as a system of rules and regulations-taxes, building codes, rules of ownership and tenancy. It can be thought of as social relationships and social institutions-neighborboods, organizations, ethnic groupings. It can be thought of as an arena of power and of the political arrangements which organize power. It can appear as an economic system-capital investment, supplies of labor, housing and land markets. In reality, any city is all of these. Since each way of looking represents an aspect of a single reality, any one of these ways of looking must in the end lead to 
the others. Nevertheless, it makes a difference where one begins. [...] Each way of seeing represents the line of sight from a particular position in society; each way of seeing also proposes different criteria for what is important, and suggests different kinds of action"

(Peattie, Planning: Rethinking Ciudad Guayana. 1987: 44-45)

\section{Introduction}

In assessing the evolution of Ciudad Guayana I contend that there have been three distinct phases of planning since the 1960s. First, from the foundation of the city in 1961, the focus of the planning activity was typically proactive, i.e., planning aimed to envision a city that did not yet exist, making proposals for the city "as it ought to be." (Rodwin, $1965,1969)$ The planning model throughout this phase was overly centralized and technocratic. Second, since the mid-1980s, the process of decentralization slowly and painfully started to take root in the structures of government at the national level, and the local government in Ciudad Guayana started to claim for itself-and eventually assumedresponsibility for significant aspects of planning and management activities in the city (Bellone Hite). This process corresponds to a phase of transition, when conceptions of central, top-down planning collided with, and tried to reconcile, bottom-up demands for more local, participatory planning, fundamentally led by the city's mayors. Although this change was underway, top-down decision-making regarding major infrastructural projects and the preservation of segregation of classes in the city prevailed, reasserting both the central decision-making model and the plans of the past. I also distinguish a distinctive third phase evolving since 1999. Even though this transitional period is far from over-in fact, it may be experiencing its most critical period ever-two different phenomena are starting to drastically transform planning at the local and national levels. On the one hand, planning at the level of the city is radically changing to be markedly reactive, menacing in the process the previous plans in an ad-hoc attempt to accommodate the city "as it is." On the other hand, planning at the regional level shows an unchecked return to "developmentalism", led by the new national government's planning ideology.

Based on this analytical framework, the paper is organized into three main sections: Proactive, utopian planning: the city "as it ought to be" (1961-mid 1980s); Transitional planning: from central to local, from technocratic to participatory planning (mid 1980s-1998); and Reactive, fatalistic planning: the city "as it is," plus a return to developmentalism (1999-). Finally, in the section Rethinking Ciudad Guayana Today, I offer some general thoughts on the significance of the transformation of the planning model in this case and offer suggestions on how best to approach critical urban problems in Ciudad Guayana at the onset of the new century. Since Ciudad Guayana reached its $40^{\text {th }}$ anniversary in 2001, and considering the prominence the government continues to give the city-region as a primary planning unit within the current national economic crisis, a reappraisal of the process through which the city has gone, and an analysis of the singular moment it is currently undergoing is overdue. This article thus engages a critical review of the political, social, and environmental axes of this renewed planning process, both as they are defined by the government and as they are appropriated, redefined, and/or contested by old and new agents of the city, particularly the newcomers.

\section{Proactive, utopian planning: the city 'as it ought to be' (1961-mid 1980s)}

The development of Ciudad Guayana has been critically assessed by Lisa Peattie and others (García, 1987; Vila, 1987a, 1987b; Castañeda and Césaris, 1987) and I add to that analysis by summarizing the extensive and revealing findings of the literature up to 
the 1980s. I briefly highlight what I consider the most valuable insights of the work of those authors, and discuss 'developmentalism' or modernization theory, and its spatial child, growth pole theory, as the conceptual basis of the mega-project enterprise that was the Guayana regional development project (Robinson 1976).

The planning process of Ciudad Guayana in the 1960s and 1970s was studied by many of the people who were personally involved in the process, planners and engineers both from the MIT-Harvard Joint Center and their Venezuelan counterparts. There is, therefore, a fairly significant amount of literature that covers what occurred in those two decades. All that work, however, mostly presents a biased, dual point of view: on the one hand, that of the design professionals - architects, urban designers, and planners and, on the other hand, that of the economists involved. ${ }^{1}$ While all these actors were designing the platonic city, enormous local boosterism and entrepreneurship activity were furiously shaping the aristotelian city.

There was only one anthropologist in the U. S. planning team of the 1960s, Lisa Peattie, whom could do little to integrate the two opposing perspectives, or help create a new, integrated one. In part, this was because she herself was also struggling to make sense of the experience. Following the anthropological tradition, she wrote The View from the Barrio in 1968, a book that directly portrayed the way in which the process of planning the city was viewed by the disenfranchised inhabitants of informal settlements, and how it impacted them. Twenty years later, in 1987, she produced a singular work on the subject of planning Ciudad Guayana that portrays the complex politics involved in the process from the multiple points of view of the disparate participants. ${ }^{2}$ The book, Planning: Rethinking Ciudad Guayana, has become very relevant within the planning literature.

In the 1960s, development specialists in the U. S. pressured to present alternatives to the marxist account of social development, used the term modernization to describe the processes of structural differentiation by which "traditional" societies could be transformed into complex, "modern"societies. Thus, modernization theory claimed that less developed countries could eventually accomplish the industrialization level of the more developed ones if they emulated the social and economic system of Western capitalism, and specifically, the values current in the United States of the 1960s. The prevailing development ideology of the American planners was represented in Rostow's, Stages of Economic Growth (1960). The concept of growth poles, developed by the French economist Perroux (1955), which was born as a non-spatial idea of leading economic sectors, was rapidly combined with the growing interest in regional planning in the U.S., to become a spatial concept of concentrated capital and industrialization in underdeveloped places to promote regional development and national spatial equilibrium. The experience was soon to be rationalized by a renowned planner of the team at Ciudad Guayana, John Friedmann, in his book Regional Development Policy: A Case Study of Venezuela (1966).

It was only later that the ideology of modernization or desarrollismo was attacked by Latin Americanists for its over-simplification and ethnocentrism. In the late 1960s, the newly developed "dependency theory" severely questioned and condemned projects such as "growth poles" as propitiating the continuation of imperialism and underdevelopment (Frank, 1969; Cardoso, 1969). Eventually, this theory was also charged with over-simplification, and accused of solely inverting the assumptions of the previous one, when proposing that the failure of Third World countries to accomplish development was caused by their forced dependence on the advanced capitalist world, i.e., the theory posited that the Third World was doomed to underdevelopment because its surplus was appropriated by the advanced capitalist countries. Much has changed since then. ${ }^{3}$ The emergence of the Asian NICs (newly industrializing countries) challenged the validity of the assumptions of dependency theory—as these countries achieved late industrialization; and proved 
the need for more sophisticated and differential approaches to Third World development. Today, economic and spatial determinisms are broadly questioned, and a holistic concept of quality of life and its equitable distribution is more central to the debate on development than the mere production of wealth. Even international agencies such as the World Bank and the Inter American Bank have changed their developmental strategies, experimenting with the goals of accomplishing the satisfaction of basic needs, redistribution, democracy, equity, and governance and participation, rather than focusing exclusively on the pursuing of progress through economic growth. ${ }^{4}$ Since the late 1980 s, postmodern critiques have identified not only the existence of alternative modes to development, but alternatives to development altogether.

After years of dictatorship, and under a petroleum-driven economy, the democratically elected government of Rómulo Betancourt proposed Ciudad Guayana in 1961 as an industrial growth pole, to promote economic growth and decentralized development distant from the northern capital, Caracas, and its extended metropolitan region. Within a climate of political instability and a fragile democracy, the new political elite thought that a focus on technocratic planning to promote growth, rather than on the restructuring of institutions and redistribution of wealth and power, seemed both safer and faster. The leaders of the newly-born democracy needed to distinguish it from the past. In order to accomplish that aim, they supported the creation of the Guayana regional development project-and its focus, Ciudad Guayana-as a project that could spur nationalism, unite the country, diversify the economy, balance growth, and serve as a international flag for the accomplishments of democracy.

The oil economy had brought rapid modernization to Caracas. It was therefore expected that capital investment and industrialization should produce the same results in Ciudad Guayana. Besides, the conditions for the location of a growth pole in Ciudad Guayana were splendid: a beautiful natural site in the lower Orinoco at the confluence with the Caroní River; plentiful natural resources (hydroelectric power, iron, bauxite, ore, transportation and basic industry); the concurrence of international planning expertsthe Joint Center; and a rich, independent national agency with ample legal powers-the Corporación Venezolana de Guayana (CVG).

At the time, beliefs in the construction of "material progress" through planning, and the "trickle down" effect of wealth, were ideas very much in vogue. The ideology of progress was further supported by a widespread admiration of the image Venezuelans had of American-style capitalism and progress, derived, in great part, from the perception of the managerial elite that ran the American enterprises and company towns in Venezuela. Since Brazil was searching for experts to compete in the design of its new capital Brasília, for the Venezuelan elite which had become accustomed to "importing modernity," it seemed only natural "to import technical skill: to buy planning" (Peattie, 1987:26).

Following this logic, the attraction of developed enterprises and skilled professionals and technicians to the site, was a strategy much preferred to the complexities and delays to be incurred in developing people and resources in country. Though the imported planners expressed a desire to provide for some degree of social class mixture, they soon found themselves collaborating with the segregation of low-income people in the city, yielding to the goal of the CVG: the rapid attraction of capital and desired people through the image of a modern city. Ciudad Guayana was thus effectively divided in two using the natural barrier of the river Caroní: Puerto Ordaz to the west, and San Félix to the east (Figure 1). The CVG did not let poor people live on the west of the Caroní, and it went as far as repeatedly repressing attempts of land invasions on that side, at the same time sponsoring self-help housing projects on the western side (Voilich: 175-178). The process of the homogenization of neighborhoods was accelerated as the better-off moved 
to the new planned communities from previously mixed neighborhoods. Some designers tried to offer different options and proposed developmental strategies of infill and refill to enlarge the housing options and enhance urban quality and social conviviality. They could not, however, interest either the CVG or any private developer.

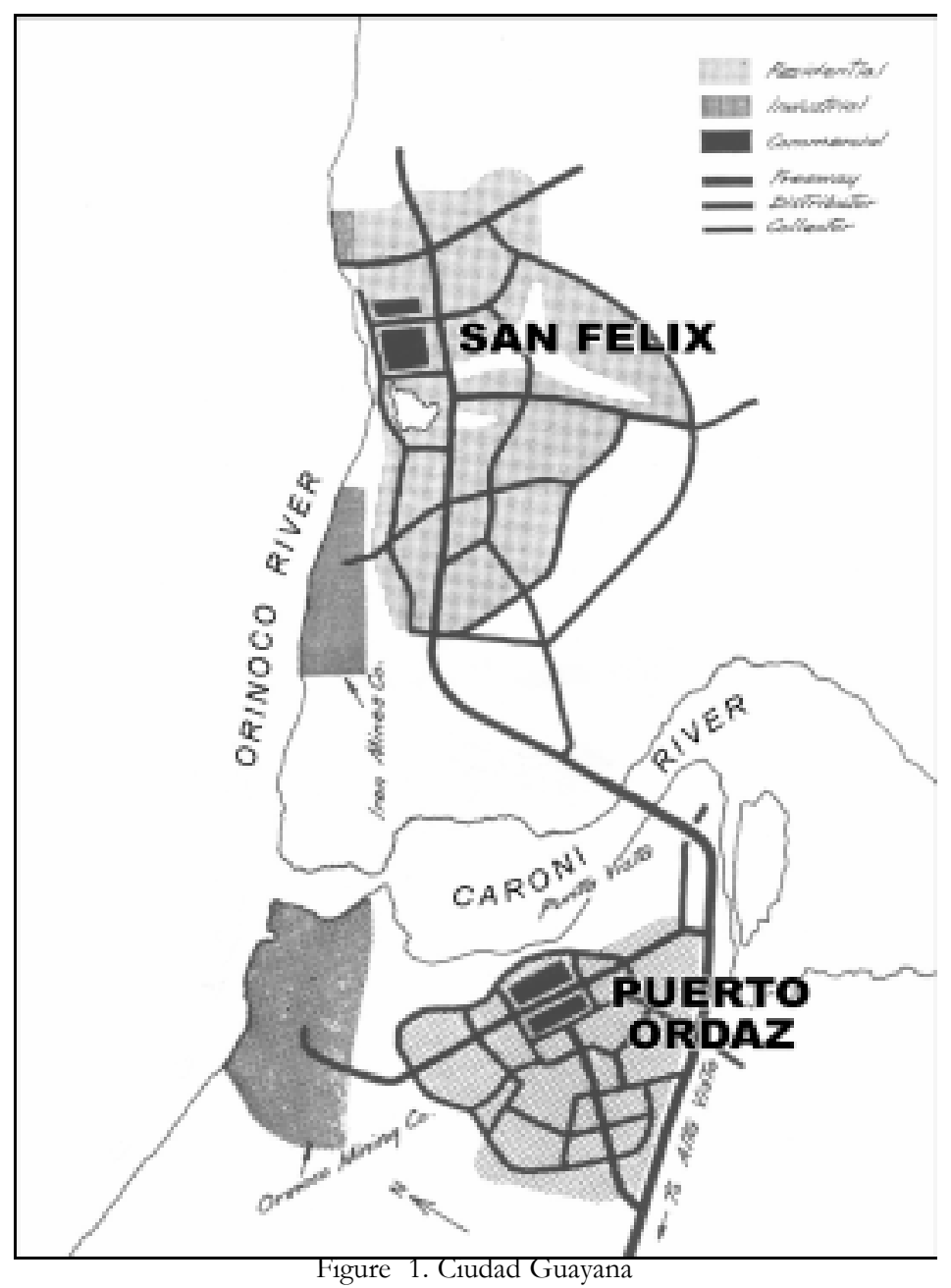

Although most stakeholders involved in the development of Ciudad Guayana shared the dominant idea of progress, their visions were quite differentiated. The engineers and economists of the CVG were committed to the building of big projects, such as the Guri Dam. The planners, thought of by the CVG group as impractical idealists, had a social agenda, however utopian and maleable it proved to be. The local business and government elite also wanted growth and public works, but only the ones that they could decide about, control, and benefit from, rather than ones imposed upon them, and whose profits went elsewhere. Hence, they resented the two previous groups. Working-class citizens and the unemployed, despite their experience of inequality, still shared a faith in progress 
and economic growth, as they realized the opening of new opportunities and some trickledown gains from the oil boom.

According to Peattie, the focus on planning the city seemed a mere modification to a program that was truly rooted in specific investment programs-the grandest among them, the Guri dam project. The city may thus have been seen as and portrayed by the American consultants as a necessary social infrastructure that could both attract the desired elite and enterprises, and showcase the government commitment to what was essentially an economic endeavor. As the city became the embodiment of the development project, and since the stakeholders in the existing disparate urban settlements at the confluence of the Orinoco and Caroní were not able to define or carry out any means of articulated opposition to the CVG's vision of community, alternatives were not available. Moreover, the disparity of resources between the CVG and the local leadership denied the possibility of any competition. Who could challenge the imported experts (based in Caracas!) with their thick felt-tipped pens "designing" the future city for its "future" residents?

Thus, as the Ciudad Guayana project was intended to achieve national goals, the current residents at the site were expected to yield their needs to the ones of the big companies to be attracted, and ultimately, to the needs of the future residents of the city, conceived as others, different from the actual ones on site. The immediate emphasis on private gain was thought to bring about social good and general progress in the long run. In general, the development agency and the planners thought of themselves as the lone agents of a transcendental historic transformation and, in this process, they did not consider or incorporate the ideas and desires of the people of the site.

The attempt of the development agency (CVG) and the planners to pro-active planning was never realistically based: it was simply overly utopian. Thus, as the local citizenry subverted the plans at every stage, planning lost its visionary quality and was left to "react", without ever developing a successful strategy to negotiate a satisfactory continuation of the planning and building process among all the stakeholders involved. Meanwhile, lured by the promise of economic prosperity, poor migrants kept coming to the city - about a thousand people a month. Formal construction in the designated urban area was soon halted and the migrants who were not planned for (though MacDonald (1969) in 1964 had warned the developers of the likely flood), simply invaded the areas outside the plan in San Félix (Figure 2), exerting enormous pressure upon the overall urban services, and particularly distorting the projections of planned urban growth and transportation dynamics.

Beside the economically-based idea of development, the conception of modernist spatial planning also bore its toll on Ciudad Guayana. The spatial results were awkward, and conveyed upon the city a somewhat inhuman quality: scattered, large buildings in vast areas, the social classes clearly separated with the poor marginalized outside the planned areas. A unilateral, physical and deterministic approach was used to address with urban design the uneasy problem of social divisions, creating a city center and several neighborhood centers. In San Félix, on the eastern side of the Caroní River, the shaded space of its historic plaza was changed for aexpanse of concrete, with a ring of squatter settlements surrounding it. In Puerto Ordaz, on the western side of the Caroní, scattered groupsof commercial office blocks and many high-rise residential developments for middle and high-income people were created on top of the existing U.S. steel company town (Figure 3). Puerto Ordaz was overbuilt, and despite the demand for housing, 40 years later there are still a number of vacant, unaffordable apartments in the formal city. 


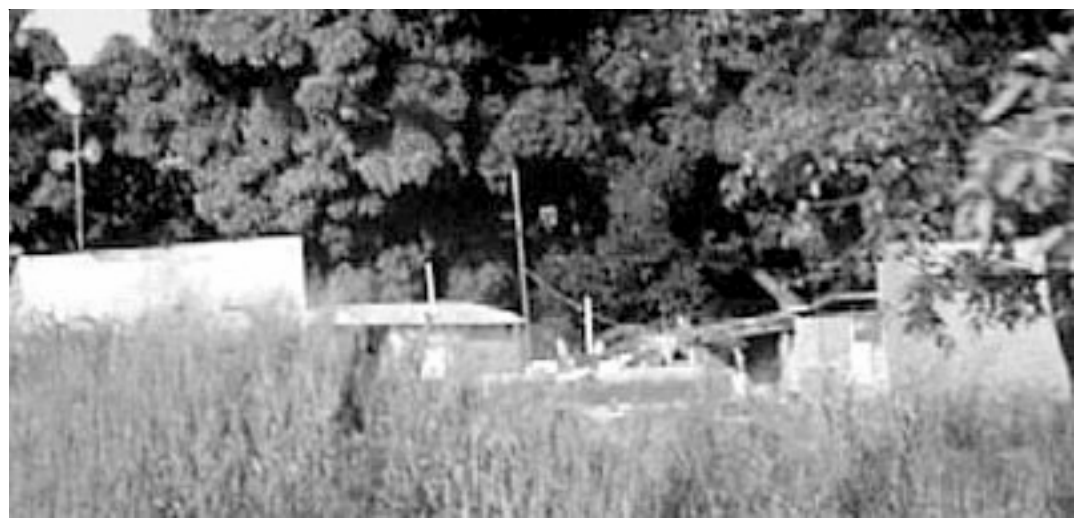

Figure 2. San Félix shanty-town

(Photo by author)

Puerto Ordaz was overbuilt, and despite the demand for housing, 40 years later there are still a number of vacant, unaffordable apartments in the formal city.

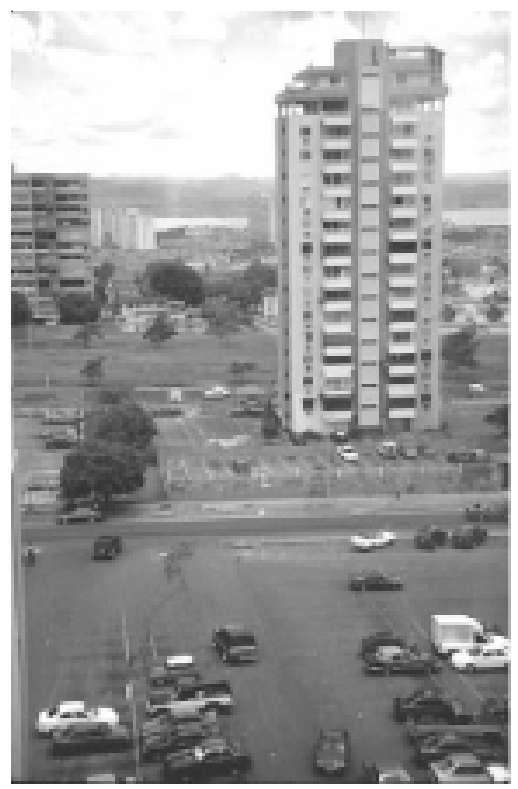

Figure 3. Puerto Ordaz apartment block (Photo by author)

Despite the enormous investments in Ciudad Guayana during these decades, ${ }^{5}$ there were many economic problems that influenced the failure of the city to accomplish national expectations, among them: lack of managerial capacity, patronage, mismanagement, and the dramatic decline in oil, steel, and aluminum revenues. More significantly, however, is that the city's failure to accomplish its goals should also be though of as the 
direct result of planning, however unconsciously or unintentional by the planners. For Peattie, planners were used or manipulated. Planning, in her view, was simply driven by the hoped-for projects. In this cynical view, planning became

“... an umbrella of coordination and legitimization for projects. If projects are the outcome of the plans, it is not because the planners thought them up in the course of planning as a way of realizing their general objectives; they were there all along, hiding under the planning process. The general objectives are secondary, rationalizations. [...] Thus a comprehensive plan may perhaps best be thought about as a cluster of projects, coordinated and rationalized under the umbrella of planning." A project, on its part, is "an embodiment of a structure for a small group sharing a common interest"

(Peattie, 1987: 154-155, my emphasis).

Ciudad Guayana was meant to become the physical embodiment of the ideas of progress and modernity. Yet, the contradictions between the functions of accumulation and legitimization that the capitalist state attempted to fulfill-according to a marxist urban analysis - were hidden through the promotion of spatial segregation-i.e., paying for the affluence of some with the misery of many. Spatial segregation, then, allowed for the planned city-Puerto Ordaz- to become the showcase of modernity. The other city of squatter settlements-San Félix-was not planned for, hence, it was possible for the agents that created the inequality to avoid responsibility for it in the eyes of the deceived observers. In this machiavellian game, "[i]deology, planning practice, and political institutions supported each other" (Peattie, 1987: 164).

From the planning point of view, the major objectives for Ciudad Guayananamely, economic efficiency, amenity, social equity, and community - not only were not achieved, but in a certain way they were subverted. The distribution of population and social classes between Puerto Ordaz and San Félix is not balanced as planned (Downs 1969). Some $75 \%$ of the population live in San Félix, whereas a similar percentage of jobs are in Puerto Ordaz, causing great transportation inefficiencies-long commutes, and severe bottlenecks over the Caroní River bridge. San Félix lacks basic amenities: many squatters go without paved roads, drainage, sewerage, water, and schools. Puerto Ordaz, on the other hand, despite its housing of more enfranchised classes, is not pedestrian friendly, and lacks articulation and plazas, parks, and green areas. There is conspicuous lack of human scale, and the visual structure offered by the planners has not been fulfilled. Anyone visiting the city today would find little value in the view that "Ciudad Guayana will develop a memorable image that will be an inspiration to the inhabitants and visitors alike" (von Moltke, 1969: 146.)

Equity-wise, there is readily apparent disparity between the two parts of the city, promoted by the way funds have been invested. ${ }^{6}$ Community building was impeded by the segregation encouraged by zoning and policing instruments, the homogeneity of residential areas, and the reinforcement of the natural barrier of the river. When plans could have produced different results, enforcement failed. So significant was the failure of planning to bring the desired outcome, that Ciudad Guayana continues to be an ideological construction: a city that almost only exists in the mind of planners and government officials, but that has failed to conquer the imagination of the people on the site and in the country, that still speak of and refer to the distinct settlements of Puerto Ordaz and San Félix.

In conclusion, the two towns existing on either side of the Orinoco river upon which Ciudad Guayana was created, Puerto Ordaz and San Félix, developed further apart 
from each other-in terms of their level of urban services and amenities-as a result of the design and implementation of the city. Despite their idealistic intentions not to cause inequalities in the new planned city, the planners of Ciudad Guayana directly caused this socio-economic and spatial polarization through their allocation of land uses and their failure to understand and engage the creation of the city as a socio-political process. In addition, the national agency CVG played a major role at perpetuating and exacerbating the dualism between Puerto Ordaz and San Félix by the differential way in which it allocated investments for urban services and industries, and defined and enforced housing policies between the two sectors of the city.

\section{Transitional planning: from central to local, from technocratic to participatory planning (mid 1980s-1998)}

Although residents of the settlements were very active as agents of historical transformation of their city from the 1960s, and there was significant organization in the neighborhoods since the early period of planning, it was only in 1977 that neighborhood associations became legitimized by national legislation. By the early 1980s, there were 62 in San Félix and 19 in Puerto Ordaz. Their representatives could participate in commissions on zoning, environment, and education at the local level. Planning commanded from the national level, through the CVG, was still inaccessible for most people.

From the 1970s to the 1990s, implementation followed planning in a patchy way at best in Ciudad Guayana. Some parts of the plans were eventually built, some others not. For the greatest part of the 1980s and 1990s, when the oil prices remained low and Venezuela was suffering a long recession, the dreams of grandeur for Ciudad Guayana were nearly forgotten, and some local planners struggled to advocate for the more disenfranchised in the midst of an inertia of inequality as a result of the CVG's investment decisions. Administrative powers remained divided. The CVG-in Puerto Ordaz-and the municipality - in San Félix — were separate and often times antagonistic powers, which posed problems for neighborhood associations in their need to appeal to government authorities. Citizens continued to take direct action outside plans and legality, invading both land and some vacant public buildings. One thing had dramatically changed, however: the city was no longer conceived of as a tabula rasa upon which to plan a future foreign to what and who were there. Rather, its real social and urban fabric was recognized and treated as the valid asset upon which to plan.

The strong impact of personal leadership during this era is well exemplified by the powerful intervention of Leopoldo Figuerela as Minister of Guayana and President of the CVG during ten years-the second presidency of Carlos Andrés Pérez (1988-1993). He had plenipotentiary powers. Given the unprecedented concentration of resources, power, and will in his person, Figuerela came to be known as the tzar of Guayana.

Since the mid 1980s, the process of decentralization slowly and painfully started to take root in the structures of government in Venezuela and Ciudad Guayana, and the local government in the city started to claim for itself-and eventually assumed-responsibility for a significant component of planning and management activity in the city. This period, therefore, corresponds to a process of transition, when conceptions of central, top-down planning collided with, and tried to reconcile with, bottom-up demands for more local, participatory planning, fundamentally led by the city mayors.

After the first popular elections of 1989, the municipal council of Caroní (the amalgamation of San Félix with Puerto Ordaz) acquired autonomous status-up to then 
it had been subordinate to the CVG-and began its independent participation in the definition of urban development in Ciudad Guayana. The main authority of the city was therefore the mayor, Clemente Scotto at the time, who came to be the main leader who favored decentralization and promoted participatory planning at the local level.

During his six-year mandate (1989-1995), Scotto emphasized four management goals for the municipality: to widen and deepen democracy; to enhance the quality of life of citizens; to have an honest and transparent government; and to modernize the institution (Marcano and Foley, 1994). One important way in which these policies were concretized was the creation of parroquias (political divisions of the social and physical structure) in Ciudad Guayana. The criteria followed for the definition of 10 parroquias respected history, social processes, natural and built barriers, number of inhabitants, and more importantly, the will of the communities involved. Within the municipality were created the Unit of Community Development and the Unit of Urban Regularization, which consisted of one team-composed of professionals, technicians, and community representatives-per parroquia, some of which had internal neighborhood modules.

Scotto promoted an unprecedented empowerment of the local government, and opened the municipal governance model to significant public participation. After extensive public consultation carried out for the discussion of city budgets from 1992 to $1994,{ }^{7}$ the municipality created different operative units and elaborated plans for them. For a detailed account of these experiences in the Caroní municipality, see Marcano and Foley 1994.the municipality created different operative units and elaborated plans for them. These plans were coordinated by the Unit of Municipal Planning, which had the general goal of "achieving a better quality of life for the inhabitants of the Caroní municipality, through service conferment and the promotion of massive participatory and democratic processes, which enable the formation of a citizen responsible of searching for the satisfaction of her needs" (Almacaroní, 1994; my translation). In this process of internal restructuring, decentralization, and democratization of the local government, other important administrative units created within the municipality included Citizen Communication; Administration; Municipal Revenues Services; Social Development; Urban Management, and Citizen Prevention Services.

Scotto also helped to construct a better relationship between the CVG and the municipality. He started to slowly build up the institutional infrastructure within the municipality to support the incremental transfer of some planning and managerial responsibilities from the CVG to the local government. He also negotiated some appropriate partnership between the two instances of government for them to share resources and duties, aiming to increase decentralization without provoking either a traumatic change of power and representation, or a potential void of accountability. The empowerment of the local government was at the same time physically expressed in the construction of a new, bigger building for the municipality, and the urban revitalization of the surroundings, in particular, the central plaza of San Félix (Plaza Bolívar), the buildings around it, and the immediate scenic coastal area at the margins of the confluence of the Caroní and Orinoco rivers. Scotto's mandate was highly praised by the locals, paving the road for the election of his then wife as the subsequent mayor.

The succession of Scotto as mayor by his wife Soraya Medina (1996-2000), was perceived by their constituency as a guarantee of some political continuity for the decentralization and participatory processes at the level of the Caroní municipality. Indeed, Medina's intent was to follow Scotto's lead. Nevertheless she proved to lack his vision and leadership capabilities. Under the weaker leadership of Medina, the flaws of a still immature, and not fully trained and committed municipal team became evident, and the trans- 
formational impulse of many of the programs which had begun under Scotto's mandate was lost.

As this was happening, Scotto was appointed president of the CVG in 1999 by the new Venezuelan president Hugo Chávez. There, Scotto continued to promote from within, the transformation of the institution in a way that favored decentralization and a more democratic planning and management of the city, pressures that he had exerted before from outside, as the local major. Taking advantage of this unique opportunity of moving to the other end of the conflictive inter-government relationship, at the CVG Scotto also continued to open up channels of communication between the different instances of government, and helped to start a process of democratization of the institution, for so long entrenched in a rigidly hierarchical, overly bureaucratic structure. ${ }^{8}$ Nevertheless, just as Scotto demonstrated ample political savvy during his time as mayor, he seemed to lack sufficient diplomacy and tactfulness when he chose to surround himself by both his exwife and his current girlfriend at the CVG office, while he had to negotiate with Medina as the mayor. This social scandal severed the relationship between the CVG and the municipality. Scotto and Medina separated themselves both affectionately-they got divorced — and politically_ending up in different political parties.

This situation, added to the flaws in their respective political performances, eventually precipitated the removal of both Scotto and Medina from their offices. On the one hand, due to her inability to fulfill the expectations of the constituency that elected her, Medina was not reelected mayor in July 2000. On the other hand, failing to accomplish the national goals of boosting the economic recovering of the CVG, and in particular failing to concretize the privatization of the steel mill, Scotto was soon supplanted as president of the CVG. Nevertheless, the decentralization process was rolling. In 1998 the CVG had started a process of internal restructuring that aimed to focus its activities on promotion and coordination of regional plans, inter-institutional coordination of intergovernmental and public-private partnerships, and the management of its own patrimony.

The discussion now turns from the political level to the level of formal urban planning per se. In Venezuela, it is mandatory to develop metropolitan plans, known as POUs (Planes de Ordenamiento Urbano); and local urban plans, known as PDULs (Planes de Desarrollo Urbano Local). In Ciudad Guayana, reassuming the tradition of a planned city, a significant effort was put in place in the 1990s for the development of a new urban POU for the city (Plan de Ordenacion Urbanistica Ciudad Guayana). In 1991, the Caroní municipality asked the National Ministry of Urban Development (MINDUR) to be granted coordination over the POU, and after some discussion, an agreement was reached for the development of the POU as an inter-institutional project by MINDUR (the national Ministry of Urban Development); the CVG; and ALMACARONI (Alcaldia del Municipio Caroni). This agreement also constituted an advancement in the decentralization process, and a wise and much-needed arrangement of inter-institutional collaboration.

The preliminary version of the POU of Ciudad Guayana was presented in 1995, after significant consultation with experts and the incipient civic society in the city. Then, the plan stalled. Today, after nine years of the production of that preliminary version, major actors in the definition of this plan are still hopeful that it is going to be legally adopted by the current government institutions to guide future policy decisions in the city. This new plan marks a radical departure from the planning ideas of the 1960s and 1970s, calling for a more democratic, participatory transformation of the city, and the promotion of a more inclusive, pluralistic society. Before leaving his mayoral office, Scotto declared this POU as the Strategic Plan of Ciudad Guayana. Under Scotto's mandate, however, the municipality did not develop the PDUL. Rather, it was decided to produce 
"Special Plans" for sectors of the city: Altavista, San Félix, etc. The completion of the PDUL is still pending.

Today, as formal planning still struggles to regain a position of importance in the development of Ciudad Guayana, the city continues with a life of its own, and a number of planning subversions continues to appear. Among them, a subversion of residential zoning with the appearance of small businesses-and sometimes incompatible uses such as chemical industries and mechanical workshops-in the frontage of lots, becomes ever more common throughout the formal city. Also, the appearance of large shopping centers, and the walling and private surveillance of subdivisions are phenomena impacting urban areas around the globe, which are making their way unchecked into Ciudad Guayana. Still more complex phenomena of a transnational scale are impacting the city as flows of people from surrounding countries continue to be attracted to the golden legend of the promise of a better life in Ciudad Guayana. The case of poor workers from neighboring Guyana is a distinct one. They can arguably be considered now a diasporic community in San Félix, where they have managed to somewhat reproduce their homeland space and culture. Last but not least, a deep-rooted problem of social responsibility and agency exists in Ciudad Guayana, which severely hinders the opportunity for the development of a successful participatory planning model and a democratic management of the city. Given the traditionally paternalistic behavior of the CVG, people have become accustomed to receiving the urban services virtually for free, ${ }^{9}$ and they do not contemplate contributing to the maintenance and enhancement of their living surroundings, expecting that all those should be provided. ${ }^{10}$

One other significant spatial problem of Ciudad Guayana in the 1990s that cannot go without mention is its extensive urban sprawl. The city still continues to expand with low densities towards the west and the south. The western extension poses severe problems of pollution, because this zone is where most of the heavy, polluting industry is located. The expansion to the south invades areas of protection for the Caroni river basin, undermining the source of water for the city, and causing other environmental problems. The low densities also have a negative incidence in the costs of urban service provision, and the efficiency of the public transportation system. In spite of these negative consequences of sprawl and low densities, the development of growth controls for the city and incentives for higher density construction have not been discussed. Currently, the public or public/private housing programs under development are mostly of single, detached family dwellings.

As a final comment about the events during this period, a significant though isolated experience is the attempt in 1990 to give access to housing in Puerto Ordaz to disenfranchised social classes. In planning zone UD337, through a process of progressive urbanization, people were allowed to live in makeshift houses at the back of their assigned lots, while they constructed their own permanent, sturdier house at their own pace at the front. The program faced significant resistance from the CVG authorities, and could not be repeated. As this example shows, during this period, although the change for more local, participatory planning was ongoing, decisions regarding major urban infrastructural projects and the preservation of segregated classes in the city prevailed mainly as direct decisions of the CVG, with the result of a reassertion to a certain extent of both the central decision-making model and plans from the past.

It is difficult to estimate how much longer the process of decentralization or urban planning and management may take, given that it is extremely sensitive to changes in the national, state, and municipal political climate and events, as well as to the personal moves of key political figures. According to Fanny Salazar, Director of the Department of Ur- 
ban Planning at the CVG, "the urban disorder corresponds to an electoral biorhythm" (Salazar, 2000). During election times and during periods between elections and the establishment of new government authorities, the greatest number of urban irregularities is registered in Ciudad Guayana (and elsewhere in the country). For instance, more squatting activity is either encouraged or permitted, in order to either gain political support, or avoid political costs, respectively. ${ }^{11}$

\section{Reactive, fatalistic planning: the city “as it is", plus a return to developmentalism (1999-present)}

As Ciudad Guayana reached its $40^{\text {th }}$ anniversary in 2001, and considering the prominence that the Venezuelan government is giving the city-region as a primary target planning area within the current national crisis, an analysis of the city's current situation merits attention. Thus, this section provides a critical review of the political, social and environmental axes of this renewed planning process in Ciudad Guayana, both as they are defined by the government and as they are appropriated, redefined and/or contested by old and new agents of the city, particularly the newcomers, and Venezuelan planners and scholars. I specifically analyze the transformation of the urban form and quality of Ciudad Guayana and its region since 1998, when Hugo Chávez Frías was elected president of Venezuela. For the sake of clarity, I first discuss three ongoing social processes severely impacting or menacing to impact the built environment and quality of life in the city. Second, I engage the debate around neo-developmentalism as it is presented by the national government and contested by several Venezuelan urban scholars.

\section{Ongoing Events}

Among the complexity of factors influencing the current dynamics of urban transformation in Ciudad Guayana, I select three of them to focus on that I believe have most critically affected the city during the early 2000s: First, the new phenomenon of land squatting in Puerto Ordaz; second, the creation of a new city in proximity to Ciudad Guayana, for the relocation of displaced population; and third, a huge urban renewal plan envisioned for the margins of the Caroní River in Puerto Ordaz.

\section{Squatting in Puerto Ordar}

Squatting on land in Puerto Ordaz increased sharply after Chávez was elected President in December 1998. His incendiary speeches and populist discourse at the beginning of his term, empowered many people to take redistribution into their own hands. Chávez specifically promised land and housing for everyone (without explaining how and when this was going to be achieved), and prohibited the use of police or military force to halt invasions. Given the shortage of affordable housing in the country, and the economic crisis that plunged the life of $83 \%$ of Venezuelans under the poverty level, the conditions were ripe for unprecedented squatting on land and in unoccupied buildings that characterized the peripheries of the major urban centers of the country. Nowhere was the phenomenon more notorious, however, than in Puerto Ordaz, a city that had managed to remain almost completely free from squatter settlements throughout its history. The process was also distinct in the sense that it encompassed a wider spectrum of social classes: not only poor, uneducated people were squatting, but also middle class, educated professionals, both frustrated by their lack of opportunities, and empowered by the encouragement given by the President. Although some selective control of squatting was made (for 
example, to protect the area where powerful military or police officials lived), other vast areas that were part of the planned city of the 1960 s that were still vacant, were left unpoliced for the first time in the hands of squatters. Squatting thus went on for several months.

Slowly after Chávez assumed the presidency and carried out a deep restructuring of the national governmental institutions, the newly created national planning agenciesMinistry of Planning and National Coordination of Housing (CONAVI) - together with the Technical Office for Housing OTV (Oficina Técnica de la Vivienda, a new local intergovernmental institution for housing in Ciudad Guayana created in 1999, with the participation of the INAVI, the CVG, the municipality, and 13 other national and regional institutions), started to address the problem by halting new squatting, assessing the condition of the squatting that had already occurred, and making plans for the consolidation of the new settlements. At the beginning of the assessment, it was estimated that there was a deficit of 40,000 housing units in Ciudad Guayana. With the support of the OCEI (Oficina Central de Estadística e Información), a careful survey was undertaken in 1999 which determined that among the invaders, there were many people that did not need housing- they were just taking advantage of the opportunity in order to obtain a new housing unit. Still, the housing deficit amounted to some 18,000 units. The CVG granted 700 hectares of land to be sold cheaply in easy installments to accommodate 15,000 families.

This approach to planning is what I call reactive, fatalistic planning: in this case it even goes beyond the unquestioning acceptance of the city "as it is": a platform par excellence upon which social and economic confrontations get played out, and hence, results in "fatalistic," i. e. "better" or "worse" urbanism-for which the only possible course of planning engagement is a "reaction". Rather, it promotes the city as the material basis upon which a new social order of what is perceived as more equitable distribution of resources is going to be unashamedly and openly established, under the blessing of the national government. This happened not only due to the anxiety of better-off people who feared for their properties, but also for the disquiet of planning professionals who felt that the development of the city ought to be more carefully considered and organized, even if it were for the promotion of a new, lasting social order. Fortunately, this concern has found an echo in the attitudes and actions of some professionals of the new national planning agencies which, as was mentioned, are starting to plan for the better organization and consolidation of the marginal urban settlements that were allowed to expand in a chaotic manner. ${ }^{12}$ In addition, with the help of the OTV, people are starting to organize around "civic housing associations," of which there are now some 400 , to negotiate with the CVG for the acquisition of land and services.

As these planning processes are just beginning, significant challenges lie ahead both for the generation and allocation of resources to carry out the consolidation of the squatter settlements, and for the prevention of more squatting.

\section{Pueblo Guri}

The second factor which has significantly affected Ciudad Guayana is the creation of a new city-Pueblo Guri-in proximity to it, for the relocation of displaced population due to the tragic floods and mudslides that happened in the coastal and Andean regions of Venezuela in December 1999. These events killed thousands of people and displaced other thousands of residents, precipitating the country to a state of planning emergency, and causing the planning process of Ciudad Guayana to emerge as one of the highest governmental priorities, for some 10,000 of the displaced were rapidly relocated into Bolívar state south of the Orinoco. At first, a stock of vacant apartments existing in 
Ciudad Guayana was used to temporarily relocate the displaced. These apartments had been constructed according to the demographic projection of the city in the 1960s and 1970s, which was never fully accomplished. As part of the formal city, the apartments could not be afforded by the poor residents of the surrounding squatter settlements.

In a second phase of government help, the workers of Edelca Co. at the Guri Dam (a one-hour car trip from Ciudad Guayana) were relocated within their camp next to the dam and their apartments used to semi-permanently relocate 522 families, mainly coming from Vargas (the coastal state most affected by the landslides). They were given humble, yet proper housing (for many better than what they had ever had in their original places), some furniture, regular food supplies, and a minimum monthly salary per family. In addition, they were offered some training in sewing, carpentry workshops, and the like. Yet, there were no jobs at the site. As the months passed many undesirable consequences started to develop. Some had become accustomed to receiving everything from the government, and expected that that situation was going to continue indefinitely. Others became very frustrated by the lack of jobs and alternative activities, ${ }^{13}$ and had succumbed to the influence of alcohol or other vices. Besides, the residents were severely controlled and isolated. As the camp is considered a strategic site next to the Guri Dam, it was under military control. Anybody going in or out of the camp needed a permit. Furthermore, there was no public transportation between the camp and the surrounding cities so, lacking private cars, they are not able to go to Ciudad Guayana or any other city. ${ }^{14}$ With these conditions, the site was functioning, in a sense, as a type of refugee camp.

Yet, some residents kept faith and began to organize the community. They elected representatives and formed a junta parroquial, so as to attain a legal status that allowed them to have access to other instances of government and be heard. The majority of the people remain hopeful of the government's promise of a permanent house. For that, a town called Pueblo Guri was planned for 1,500 houses next to the current camp. Camp residents were hired for the construction, so some of them will have jobs for the duration of the works. Yet, while more than 10,000 people are expected to live there (other displaced persons currently located in other areas of Bolívar state were being brought there too), there are few jobs. Unfortunately, the founding of a town without any economic basis appears doomed to failure. Surprisingly, however, the vested interests of the government on the one hand, and of the displaced people on the other, seemed to temporarily affect their judgement. Pueblo Guri could thus be considered a new instance of utopian planning that is affecting Ciudad Guayana.

However, such an illusion cannot persist. When the residents of Pueblo Guri are left on their own, without the all-encompassing support from the government that they have been receiving, they will have no choice but to leave the town in search of sustenance elsewhere. It seems reasonable to expect that a significant number of residents of Pueblo Guri-who lost all ties to their places of origin - may try their luck in the closest large urban center, i.e., Ciudad Guayana. Should this happen, another round of reactive, fatalistic planning would occur in Ciudad Guayana: people will squat on the urban land of the "planned city," and authorities will be forced to try to plan for their settlement as best they can, but only after the fact, as a reaction to the invasions.

Empirical observations also indicate that some other relocated persons, who had accepted the move to Guri attracted by the offer of an apartment and a new beginning, have been returning to their previous coastal towns, notwithstanding the current precarious conditions of these locations and their dwellings. This outcome, however, comes as no surprise. As often happens in relocation projects, the psychological ties of the relocated to their original places_ _ sense of belonging to a place and community — and their 
practical ties-job or type of skills, vocation (e.g., to perform jobs related to sea, rather than to land) - exert such an influence on these people as to empower them to go back to where they feel they best belong.

It is hoped that the realization of the current processes would prompt the national government and planning officials to reevaluate their positions regarding development in Ciudad Guayana and its region, and redirect their efforts. Something quite distinct to reactive planning could happen instead, if immediate planning measures were considered to accommodate the de facto growth that has occurred with the invasions and the one that is forecasted due to the ongoing events. Fortunately, the setting and the conditions of Ciudad Guayana could accommodate this growth through infilling and densification, if it were properly planned.

\section{Caroni Tourist Center}

The third significant spatial transformation in Ciudad Guayana will undoubtedly result from the huge urban renewal plan that is being planned for at the margins of the Caroní River between the two Macagua Dams. The plan, mostly conceived of as a tourist development, envisions an overall transformation along the edge of the river, contemplating among other aspects, some full-spa tourist developments on a grand scale. The opportunities for the development of these complexes will be offered to large national and international corporations. At the moment that this article is written, this process is dormant, given the reduction of international investments in the country due to its political instability. The bright side of this otherwise gloomy picture is that it affords the opportunity for the planners to reconsider their goals. At a conceptual level, the idea of incorporating the areas at the margins of the Caroní, which traverse all the southeast border of Puerto Ordaz and the west of San Félix, to the dynamics of Ciudad Guayana is not only plausible, but very desirable. There are countless examples of cities around the world that have made waterfront developments one of their greatest assets. Perhaps one of the greatest flaws in the planning of Ciudad Guayana has been the neglect of attention to the potential assets that the rivers afforded, and around which the city could have been planned, rather than simply bridging the Caroní and turning its back on them. However, there are a number of very delicate issues that need to be carefully considered now that development of the waterfronts is contemplated. Foremost among them are critical environmental and social aspects.

From the point of view of the natural environment, the river margins are very fragile ecosystems. To develop them requires a candid, careful consideration of the difficulties present, ${ }^{15}$ and the measures that need to be taken in order to preserve-and even enhance - the quality of life of its flora and fauna, the condition of its water basin, the quality of water sources, soils and air, etc. Strict conservation measures ought to be defined and enforced to regulate the construction of buildings and recreational facilities, transportation along the river, and water-based recreational activities and sports. Similarly, controls ought to be defined and enforced to regulate garbage and toxic disposals, as well as recycling and maintenance issues. The development and implementation of a system of positive and negative reinforcements of these goals should encourage all agents to become engaged in the conservation of a healthy environment and to comply with rules for its appropriate use.

The social aspects of the project may be still more difficult to grasp and manage than the environmental ones, notwithstanding the complexities and importance of the latter. For the decision makers, it will be important to keep in mind at all times in the definition of the project exactly who is going to be favored by the policies and actions 
taken. Inclusion and equity should be made prior social goals. That the main area under consideration for the waterfront redevelopment is in Puerto Ordaz rather than in San Félix is already a factor that may have enormous implications for the differential way in which residents of these two sectors of Ciudad Guayana have access to the benefits of such development. This needs to be carefully considered so that measures can be taken to try to assure an inclusive and equitable social distribution of benefits. From the economic point of view, the profits for large public and private investment within the area, as well as for public-private partnerships, should be balanced, monitored, and made accountable. Private investors must pay their toll for the right to develop and profit, without excessive public abatements or financial support; and the government should reinvest its assets in a manner convenient to the community. In addition, opportunities should be created and respected for small entrepreneurs to carry out economic activities derived from the new demands from the development, and for local workers to find decent jobs. From the physical point of view, a proper mixture of functions, including residential (and particularly affordable housing), should be defined and enforced for the new developments. In addition, access to the coast should remain public not only for strategic purposes, but also for the population at large to have access to recreational opportunities in varied pathways, parks, and beaches, all designed with sustainability in mind.

For the most part, the margins of the Caroní River comprise vacant land owned by the CVG. This fact makes it fairly easy for governmental and planning institutions to offer the land for this grand tourist scheme. The plans face a curious difficulty, however: there exist a few squatter settlements or barrios (Toro Muerto and Santa Rosa) that had managed in previous decades to become established on the fringes of the Caroní River in Puerto Ordaz, in spite of all the land controls. Since these barrios are fairly consolidated and the new government is allegedly supportive of the poor, evictions are out of the question. In addition, the newly formed squatter settlements in Puerto Ordaz (discussed above) are also located in the south-west part of the city, close by the Caroní River and contiguous to this stretch of land considered in the urban renewal plan. What can be done, then, to preserve these barrios and still create an economically attractive development vision for the area? The answer planning officials in Ciudad Guayana are contemplating is a very contemporary one: the marketing of the barrios as tourist towns. Thus, it is assumed that the "vernacular", "naïve" architecture of these barrios will become reinforced and complemented by the promotion of "traditional," folk crafts among the residents, catering to tourist interests. Hence, both the built environments and the activities performed in the barrios will be contrasted with the new high-tech, full-spa tourist developments that are being planned for the area, providing the barrios with a distinct, attractive aura. The ensuing issues concerning the commodification of the built environment and the practices enacted in it are hardly trivial and need to be carefully assessed, not only from the economic point of view, but also from the anthropological and sociological ones. ${ }^{16}$

Finally, given the grand scale of this urban renewal plan and the potential impact it can have not only on the lives of Ciudad Guayana's residents and visitors, but also on the regional and even national economy and tourist industry, it is critical that it be openly and extensively discussed with all interested parties and civil society in the country.

Evidently, this urban renewal project does not correspond to what I have named 'reactive' planning. Rather, this grandiose scheme relates back to the tradition of grand planning in the city, and may be best related to the awakening of neo-developmentalism on the part of government and planning institutions leading the definition of the future of the city. I hence turn to the discussion of this phenomenon. 


\section{A return to Developmentalism}

In 1999, a new government came into power in Venezuela whose purpose, in its own words, was to "re-found the Republic." The bases of the new Republic were decided upon by a Constituent Assembly elected in July of 1999. The assembly members laid out a new "Bolivarian" Constitution, which in turn was accepted by the Venezuelan constituency in a national referendum held in December 1999. The new territorial policy, although not part of the constitution, is one of the showiest elements of the intended refoundation. The relevance of reviewing the current state as well as the potential of Ciudad Guayana 43 years after its foundation and in light of the new national territorial policy cannot be overemphasized, since the current Venezuelan government has been revisiting the idea of making Ciudad Guayana part of a major regional axis of development. In doing so, the government is proposing Ciudad Guayana as a key urban center in a regional development project along the Orinoco-Apure river basin axis, which encompasses some 300 thousand square kilometers esat to west of the country, far south of the urbanized coastal zone. Distinct from the idea of the industrial "growth pole" that animated the planning of the city in the 1960s, this time the urban and regional "growth axis" project is intended not only to overcome territorial and economic imbalances by means of "concentrated decentralization", but also to respond to political and social demands, while paying attention to environmental concerns unattended in the previous planning processes in the region (Buenaño, 1999, 2000).

Yet, current events in Ciudad Guayana raise the question: is planning in Ciudad Guayana being inspired by neo-developmentalism and growth-pole approaches? As previously explained, modernization planning assumed that the concentration of industries and technology in growth poles would diffuse economic growth and modern life-styles in the surrounding regions. The government seems to be betting on that once more. The ideological roots of the project are laid out in the First National Plan of Territorial Development (FNPTD), developed in February 1999. In this document, the project OrinocoApure is outlined as the central strategy of national development, to the point that it is defined as a "flag project" and as "a revolution in-and-of itself", together with the others two "axes of deconcentration" proposed. President Chávez has traveled around the world showcasing the project in search of investors, claiming that it has sparked much interest. Pedro Olivieri, Vice-President of Planning at the CVG, called "impressive" the investment interest in Guayana, noting that Australians, Japanese, Koreans, Mexican, and American groups have recently explored investment opportunities in the steel industry of the region (Olivieri, 2000). However, it is already known from the experience of previous decades in Ciudad Guayana, that main local and regional—and even national-benefits do not rest in the development of primary economic sectors, much less so if the investment is foreign. The key to economic diversification and a more equitable distribution of benefits is the promotion of linkages (encadenamientos) between the major investments, i.e., the generation and networking of secondary (other industries for the production of surplus value), tertiary (services), and quaternary (informational services and production) economic sectors.

In the FNPTD and all the official statements on the matter, the absence of analysis on the role of existing urban centers and urban networks is notorious. Instead, in terms of resource allocation, this growth axes projects is presented as an opposing alternative to the consolidation of the large urban agglomerations of the northern part of the country. The government manifests the intent to sponsor territorial deconcentration time and again, ignoring the empirical evidence that shows that generally, the investments that produce greater growth and diversification—and eventually more deconcentration-are 
those which are made in the more urbanized regions. On the other hand, investments made in territories whose population and infrastructural development are still weak tend to produce enclave effects and their contingent networking occurs, if at all, toward the aforementioned more urbanized regions. This effect paradoxically reinforces the concentration that it was meant to combat. Precisely, these are the reasons for some of the problems that the development of Ciudad Guayana has demonstrated, and that the government should take into account for current planning.

Marco Negrón has mounted the strongest and most insistent opposition to the Orinoco-Apure plan (Negrón, 1999, 2000). For him, the new territorial policy attempts to formulate the need of a radical transformation of the historical trends of territorial occupation in the country; i. e., it intends to move to the south what is to the north, carrying it out mainly through the development of the Orinoco-Apure river axis project. Even when this position is presented as a territorial revolution, what is really at its basis are old anti-urban biases rhetorically justified as the quest for national spatial equilibrium. Official statements brush the dust off the old theses of internal colonialism and spatial determinism, to propose the deferment of the development of urban Venezuela in an attempt to benefit the rural. Both the experiences in Venezuela and abroad, however, have revealed time and again that these attempts favor neither the urban nor the rural worlds.

Playing out a contradiction that Negrón calls a "revolutionary rhetoric vs. contrarevolutionary practice," the arguments of the government to resuscitate that "growth axis" project are surprisingly the same of decades ago: the cost of providing services and bringing water to Caracas, and the wealth of natural resources of the southern territories. The first argument is suspect, because if the cost of pumping water to Caracas from low level water basins, then the elimination or at least attenuation of the subsidies of the current consumer bills for urban services tariffs ought to be considered. The second argument is inconsistent because the existence of natural resources in a region-especially if they are non-renewable, mineral resources-does not imply the desirability of promoting intensive processes of population growth. Indeed it may be sensible to not offer incentives to populate such regions.

In 1999, in a country submerged in a deep economic crisis and suffering from political unrest, work on the Orinoco-Apure project was evolving slowly, facing significant controversy and opposition, when natural calamity hit in December of that year. The series of landslides and floods that swept away a number of towns in the coastal and Andean regions of the country, killed thousands of residents and left other thousands homeless and jobless (USGS, 2000). Facing the urgent need of relocating these people and providing them sources of sustenance, the Venezuelan government again gave the Orinoco-Apure a high priority in its agenda. Disgrace was turned into an opportunity for the government to advance the project without the need to face and respond to the significant controversy that had arisen over its value. Urgency and widespread feelings of human solidarity amidst the Venezuelan society gave the government a political advantage in relation to those who opposed the project on its own merit. The government claimed a moral imperative to facilitate housing and employment for the victims of the landslides away from the risky areas of the northern urban conurbation. It started to plan new towns along the Orinoco-Apure axis and other rural areas of the country-one of which is Pueblo Guri, referred to above. The government also created a discourse in which it stopped referring to the victims as damnificados (one who has been subjected to loss), and instead calling them a name of similar sound but radically different meaning: dignificados (dignified). According to this renaming, the victims ought to feel fortunate, because their status was to be elevated: prior to the tragedy they lacked dignity, ${ }^{17}$ extremely adamant not only against the plan, but also pinpointing the responsibility of its ideologi- 
cal designers, when he said: "The risk that we run today is not that those mythologies finally materialize, but once more that of the resource dilapidation and the loss of time to the hunting of ghosts nestled in the head of some irresponsible "dream maker"18 (Negrón, 2000). Other Venezuelan scholars and planners that have publicly expressed concern about the way the Orinoco-Apure axis project is being conceived by the government include Frank Marcano, Sonia Barrios, Helia del Rosario, Oscar Tenreiro and Marta Vallmitjana, among others (Analitica, 2000). ${ }^{19}$

I share their views on the marked ideological arguments that support the project, and the revival of previous anti-urban theories and practices that have been discarded in national and international contexts, due to abundant empirical evidence that proved their pitfalls. These critics firmly believe that the maintenance and upgrading of the level of services and quality of life in the northern megalopolis and the national network of current major cities-which have dramatically declined in the last two decades—are the most efficient choices for the promotion of development in the country and competitiveness in the global economy. If what is sought is to stimulate the development of the south, on the other hand, a more efficient way to accomplish it would be to support the current industrial agglomeration of a million inhabitants represented by Ciudad Guayana and Ciudad Bolívar, rather than initiating a major new project within a much larger geographical area.

\section{Rethinking Ciudad Guayana today}

Since the 1960s, Ciudad Guayana has been the subject of an unmatched urban planning process that has aimed, with different goals in each period, to radically transform its physical, social, and political nature. The city thus offers a unique case study to investigate the relationship between urban governance and planning and its influence on the built environment. As the example of Ciudad Guayana shows, planning can yield results that prove to be totally antagonistic to its expressed intentions, i. e. planning can engender a series of social processes that provoke paradoxical spatial results with regards to the government officials' and/or planners' utopian goals. Today, Ciudad Guayana presents tremendous paradoxes that have grown ever sharper since its inception. So far, the city has failed to accomplish the objectives that both the national Venezuelan government and American and Venezuelan professionals had envisioned for the city and region. For instance, in spite of the attempt at national deconcentration that fueled the planning of the city in the 1960s, for the last 40 years more than $70 \%$ of the population and more than $75 \%$ of public and private investment have been located in and around Caracas, the country's capital (Buenaño 2000).

In his critique of Brasilia, Holston (1989) presents that city as a "blueprint utopia", i. e., the ultimate and grandest attempt to modernization and modernism. However, he identifies a myriad of ways in which this "utopia" has been subverted by the people who migrated to inhabit it. He calls the processes that subverted the grand plans the "Brazilianization of Brasilia," to mean that phenomena that were intrinsic to the sociocultural ethos and political economy of Brazil were repeated in the new capital, in spite of the opposed intentions of its master plan. Furthermore, in some cases these processes were exacerbated by the very spatial and social structure of the planned city (Epstein 1963). A similar phenomenon happened in Ciudad Guayana for which, to paraphrase Holston, one may refer to the "Venezuelanization" of Ciudad Guayana. These processes started from the very beginning of the city, when the government was unwilling, and sometimes incapable, of implementing the physical plans laid out by the planning team. The differential processes of squatting carried out in Puerto Ordaz and San Félix since 
the 1960s, for instance, and their corresponding distinct institutional responses according to both the place and historical moment in which the squatting took place, as well as to the ideology of the government at the time of the occurrence (evictions, demolitions, relocations, resettlements, and more recently, enablement and empowerment), all testify to the subversions of the planning intentions by both citizens and government officials.

This study ends by suggesting some normative recommendations derived from the analysis of each of the distinct phases of planning in Ciudad Guayana. My hope is that they assist the planning project and subsequent development of the city, avoiding to the greatest extent possible the problems of the past. It is only fair to say that some of the problems identified for previous periods have already been recognized and addressed to varying degrees by planning agents in the city. In most cases, however, inertia persists.

\section{From the era of utopian planning (1961-mid 1980s)}

Planned cities in the world, such as Islamabad, Chandigard, Brasília, and more recently Curitiba (Irazábal, 2000), have repeatedly demonstrated that planning can be used as an instrument to construct and legitimate severe social inequalities. Thus, social and spatial inequalities in Ciudad Guayana have not occurred despite the existence of planning. Rather, they have occurred to a significant extent because of the type of planning used. Some important lessons from this period are:

- Planning should not be conceived of as rigid or static. Rather, it should be a process of negotiation and collaboration to build up consensus around an adjustable path of growth and development. It should focus more on process rather than on product design. The planned city ought to be derived from its contemporary context. The rigid separation between planning and implementation in a context of complexity, change, and uncertainty also works against the desired outcomes. Along with addressing spatial design, planners should devise multidisciplinary instruments to help make more equitable the allocation and distribution of resources (land, housing, and other urban services, amenities, and opportunities). Planning should also be realistically based on the actual population of the site, its assets and potential, rather than on a preferred, higher-income population and economic base that may never materialize.

- Planning should not be used as an instrument for the legitimation of government actions that would otherwise-if presented as "unplanned"-lead to confrontations with civil society. Rather, it should facilitate the arena for negotiation, collaboration, and consensus-building, so that actions derived from those processes are legitimate and beneficial for the majority.

- Local and regional planning should be preferably carried out in the locality or region to which it relates. In the 1960s, the planning of Ciudad Guayana was mostly carried out in Caracas, and any related activities performed on the site were seen as mere "fire fighting."

- To carry out local and regional planning, the importance of comprehensive planning that links economic, social and spatial concerns, and the use of a multi- 
disciplinary team cannot be overemphasized.

\section{From the era of transitional planning (mid 1980s-1998)}

Despite significant efforts by some officials within the principal government institutions in Ciudad Guayana, there remain enormous challenges to surmount. One key element remains the effective transfer of developmental responsibility from the CVG to local government and private management in Ciudad Guayana. The secular electoral swings of opinion, the resistance of some key participants, the inertia of the bureaucratic functioning of the institutions, the technical weaknesses of the city staff, and the inadequate transfer of financial resources-all remain significant obstacles.

- There are needs for continual efforts to open up channels of communication between the different instances of government, for deepening the process of democratization of the institutions, for political commitment to decentralization and participatory processes to become strongly established; and lastly, for enhancing the technical and financial capabilities of the local institutions.

- It is also desirable that formal planning regains a position of importance in the conduct of urban and regional development in Ciudad Guayana. It is thus necessary to speed up the process of the adoption and implementation of the 1995 POU for the city, as well as the preparation of the PDUL, so that they can guide current policy decisions towards a more democratic, participatory transformation of the city, and the promotion of a more inclusive, pluralistic society.

- It is critical to educate citizens and encourage their organization so that they become responsible and active agents in the city. A key problem for the development of a successful participatory planning model and a democratic management of the city stems from the persistent paternalistic behavior that the CVG has demonstrated regarding the provision of services to citizens. The citizens' expectations are thus limited, and they behave as passive consumers, rather than active agents.

- More efforts should be put in the attempt of creating more affordable housing in Puerto Ordaz, and upgrading housing conditions in San Félix. A critical evaluation of the experience of zone UD337 may provide clues as to how to proceed in this direction, either through perfecting the process of progressive urbanization, or devising other creative public, public/private, and communal (enabling/empowering, cooperativist) mechanisms.

\section{From the current phase of reactive planning and neo- developmentalism (1999-)}

The dynamics, among the many factors affecting the development of Ciudad Guayana-mainly, the ideology of the new government, the actions of a population empowered by this regime, the pressures entailed by the housing shortage, and the need 
to accommodate displaced population-demand a critical and prompt revision of the approach to planning the city and the region.

- Since the 1960s, planning in Ciudad Guayana has faced the great challenge of distinguishing between "the planned city" and "a city that plans," rather than presenting them as the same thing. This would educate citizens and stakehold ers to understand, promote, and enforce everybody's right to both plan the city and enjoy the planned city. It would also help them to critically perceive, discuss, and sort out the social differences and contradictions that must be addressed for this to happen.

- The necessity to address the problems of balancing development between Puerto Ordaz and San Félix has become increasingly imperative. Since some of the problems of San Félix have also expanded into Puerto Ordaz, the planning expertise gathered by design professionals and government authorities should be used to prepare new models capable of promoting more sustainable, equitable development.

- With regards to the new barrios being created southwest of Puerto Ordaz, it is important that the planning processes that have recently started — namely, the halting of new squatting, the improvement in the conditions of the squatters that have already occupied sites, and the planning for the consolidation of the new settlements-are carried out carefully and thoroughly. Significant challenges lie ahead both for the finding and the allocation of resources to carry out the consolidation of the settlements, and the prevention of more squatting.

- With regards to Pueblo Guri, it is hoped that the realization by the government and planning officials of the current processes-namely, the exodus of the displaced to their places of origin, their migration to Ciudad Guayana, and the critiques of the creation of Pueblo Guri by many intellectuals in Venezuela-would prompt them to reevaluate their positions regarding development in Ciudad Guayana and its region, and redirect their efforts as needed.

- With regards to the urban renewal plan for the waterfront of the Caroní, there are a number of very delicate environmental and social issues that ought to be carefully considered. From an environmental point of view, the development of the river margins requires a candid, careful consideration of strict conservation measures and controls that need to be enforced in order to preserve- and even enhancetheir environmental quality. Within the social aspects of the project, inclusion and equity should be made prior social goals. Equally important, all agents should be educated and encouraged to become engaged in the conservation of a healthy, equitable environment. Finally, it is critical that this project be openly and extensively discussed with all interested and affected parties.

- With regards to the axes-of-development projects, there are great risks of committing the same mistakes of the past. In the midst of an analysis that totally ignores or downplays the role of existing urban centers and urban networks, old anti-urban biases of internal colonialism and spatial determinism have reemerged. Crucial questions remain to be assertively addressed: To what extent is planning in 
Ciudad Guayana being inspired by neo-developmentalism and growth-pole approaches, and if so, how can pitfalls of the past be avoided? How best can the government promote the generation of economic linkages between major investments (which were also sought for, but did not happen in the past)? Despite the understandable increase in demands created by the natural disasters that occurred in December 1999, the government should still consider the significant critiques that the Orinoco-Apure project has aroused.

- The reconstruction of Vargas and the enhancement of the current northern urban areas of the country should be undertaken while attending to other regions. The maintenance and upgrading of the level of services and quality of life in the northern megalopolis and the national network of current major cities should be given national priority, if promotion of development in the country and competitiveness in the global economy are sought. A more efficient way to accomplish the development of the south would be to support the already existent industrial agglomeration from Ciudad Bolívar to Ciudad Guayana.

As many critical urban processes are unfolding in Ciudad Guayana, more empirical research is needed to both cover and understand more fully the events and their consequences in the urban form and quality of life of the city, and contextualize them in the larger theoretical debates of planning and development in Latin America. If one examines the stream of articles by Rakowski (1985-1995) on the role of women and labor issues in the development process in Cuidad Guayana, one quickly realizes how complex the issues are, and how much more research is needed.

When Peattie wrote about Ciudad Guayana in 1987, she reflected that there were many ways of thinking about a city. None of these views are "innocent", that is without lineage or consequences. Rather, each view emphasizes different factors and defines different plans according to the subject's vantage point in society. I would encourage the current government in Venezuela to address the challenges of development in Ciudad Guayana from a holistic perspective that perceives the city and its region as much more than an economic system that can be exclusively defined from the vantage point of governmental power. Instead, the complex web of social relations and social institutions that exist in the city should be brought into the arena of power, so that a system of rules and regulations can be flexibly defined and agreed upon by all social agents.

In reality, any city is all of these ways of thinking about it, Peattie argued, and "any one of these ways of looking must in the end lead to the others. Nevertheless, it makes a difference where one begins" (Peattie, 1987:44-5). Today, how one proceeds will also make a difference.

\section{Acknowledgements}

This research project was founded in part by the Tinker Field Research Grant, Center for Latin American Studies, University of California at Berkeley, 2000. I am grateful to Gilberto Buenaño for his institutional help, to Elisenda Vila, John Foley, Nezar Alsayyad, and Ananya Roy for their thoughtful comments, and to all the persons listed below who were willing to be interviewed for the elaboration of this project.

\section{Notes}

${ }^{1}$ Much has changed, and yet the development paradigm continues to be in some instances a strategy for metropolitan domination. For a critique on this topic, see Escobar 1995. 
${ }^{2}$ An interesting symptom of this change is that the GINI coefficient is now more often a preferred indicator of a condition of a society than the GNP.

${ }^{3}$ Much has changed, and yet the development paradigm continues to be in some instances a strategy for metropolitan domination. For a critique on this topic, see Escobar 1995.

${ }^{4}$ An interesting symptom of this change is that the GINI coefficient is now more often a preferred indicator of a condition of a society than the GNP.

${ }^{5}$ In the five years after the boom of oil prices in 1973, more than 10 billion dollars went into Ciudad Guayana from the Venezuela's OPEC riches (Peattie, 1968).

${ }^{6}$ By 1980, the CVG had invested almost 40 times more in Puerto Ordaz than in San Félix (Peattie, 1968).

${ }^{7}$ For the public discussions of the city budgets of 1992, 1993, and 1994, Scotto was inspired in part in the experience of "participatory budget" (orçamento participativo) of Porto Alegre, Brazil. For a detailed account of these experiences in the Caroní municipality, see Marcano and Foley 1994.

${ }^{8}$ This attempt to democratization is best expressed in the definition of a new mission and goals for the CVG, shown on a poster hung on the walls of all its offices, which emphasize a participatory approach to decision-making and management. In addition, for more than 10 years now, the CVG is not receiving national resources, i. e., it is financially autonomous.

${ }^{9}$ In 2002 the middle class payed some Bs. 890 monthly for water, the equivalent of some $\$ 1.25$, which was far from covering the costs of the service.

${ }^{10}$ When the iron industry was nationalized, a number of comfortable, well-maintained American subdivisions were transferred to locals. Today, these Ferrominera subdivisions and houses seem abandoned: a desolate sight of dirty, ruined, and sometimes walled landscaping.

${ }^{11}$ One of the most outrageous cases in the recent history of Ciudad Guayana is the public housing development created in the UD322 in San Félix, on top of a sanitary landfill.

${ }^{12}$ CONAVI assigned in 2000 a Bs. 200-million, 7-month contract to the CVG for a study of physical rehabilitation of barrios in Ciudad Guayana.

${ }^{13}$ When I visited the site in 2000 , after eight months of the encampment installation, the residents had very few jobs and educational opportunities. They did not even have an elementary library.

${ }^{14}$ Only recently was a bus route established between the camp and Ciudad Guayana and Ciudad Bolívar during the weekend, to allow for some recreational outings.

${ }^{15}$ Some of the more critical environmental problems existent in the area of the Caroní River are: irregular settlements in risky areas and invasions of protective areas; uncontrolled deforestation and land movements; air pollution due to industrial emissions; defi- 
cient number, access, and control of recreational areas on the margins of the river, and significant water pollution. Water pollution in the Caroní River has multiple causes. It is due to untreated sewage; chemical residues from agricultural activities; mercurial and other industrial residues from mineral and industrial activities; excess of sediments due to mineral extractions, garbage and construction debris, etc. (Marcano and Foley, 1994).

${ }^{16}$ It is also important to point out that some areas of these barrios are subjected to periodic floods of the Caroní River (Marcano and Foley, 1994).

${ }^{17}$ In Chávez's discourse, Venezuelans were treated without dignity for the last 40 years before he became President, by the previous pseudo-democratic national governments.

${ }^{18}$ It is not clear who Negrón refers to here. He may have had several people in mind: mainly, Fernando Travieso, who coordinated the First National Territorial Development Plan, together with José Pacheco, the current Vice-Minister of Infrastructure, one of the most vociferous government officials in favor of the Orinoco-Apure plan and against investment in Caracas. More significantly, though, Negrón could be referring to President Chávez.

${ }^{19}$ For their individual, extensive discussions of the topic, see Analitica Research- Foro Territorial, "Más allá de la tragedia, ¿reconstrucción o impulso al Eje Orinoco-Apure?" March 3, 2000 .

\section{References}

Almacaroní. 1994. Plan Operativo 1994. Ciudad Guayana.

Angotti, Tom. 2001. Ciudad Guayana: From Growth Pole to Metropolis, Central Planning to Participation, Journal of Planning Education and Research, vol. 20 (3): 329-338.

Appleyard, Donald. 1976. Planning a Pluralist City: Conflicting Realities in Ciudad Guayana. Cambridge: MIT Press.

Barrios, Sonia, Frank Marcano, Marco Negrón, Helia del Rosario, Oscar Tenreiro and Marta Vallmitjana. 2000. Más allá de la tragedia, ¿Reconstrucción o Impulso al Eje OrinocoApure? Analitica Research-Foro Territorial. March 2000. URL <analítica.com>

Bellone Hite, Amy E. 2002. A Planned City in the Era of Shrinking States: Ciudad Guayana's Experience with State-led industrialization and its Transition to Neoliberal Development Strategies. Unpublished Ph. D. dissertation, Latin American Studies, Tulane University.

Buenaño, Gilberto. 1999. Regional Decentralization and Deconcentration: The OrinocoApure River Basin Development Plan (Venezuela). Presentation at Symposium "Urban and Regional Links in the Global Age: Development and Integration in Latin America." The Center for Latin American Studies, the Institute of Urban and Regional Development, and the Berkeley Environmental Design Association. Berkeley.

2000. El Proyecto Apure-Meta: Una Iniciativa de Desarrollo en los Llanos Colombo-Venezolanos. Presentation at Symposium "Desarrollo Regional y Urbano en la Era Global.” Bogotá, Colombia, August 14, 2000. 
Cardoso, Fernando H. 1969. Dependencia y desarrollo en América Latina: un ensayo de interpretación sociológica. México: Siglo XXI Editores.

Castañeda, Eduardo and María Nuria de Césaris. 1987. Participación Ciudadana en Ciudad Guayana. In "Guayana 25 Años Después: Teoría y Práctica de la Planificación Urbana. Cuadernos Sociedad Venezolana de Planificación. Venezuela: CILDIS, CVG, CONICIT.

Corporación Venezolana de Guayana. 1973. Planteamiento para la Organización Espacial de la Región de Guayana. Editorial Arte: Caracas.

Dinkelspiel, John R. 1967. Administrative Style and Economic Development: The Organization and Management of the Guayana Region Development of Venezuela. Harvard University, Department of Government, unpublished Ph. D. dissertation.

Downs, Anthony. 1969. Evaluating the allocation of resources to urban development, in Lloyd Rodwin (ed.), pp. 352-377, Planning Urban Growth and Regional Development: the Experience of the Guayana Program in Venezuela. Cambridge: MIT Press.

Epstein, David G. 1973. Brasilia, Plan and Reality: A study of Planned and Spontaneous Urban Development. Berkeley:University of California Press.

Escobar, Arturo. 1995. Encountering Development: The Making and Unmaking of the Third World. Princeton, N.J.: Princeton University Press.

Frank, André G. 1969.Capitalism and Underdevelopment in Latin America. New York.

Friedmann, John. 1996. Regional Development Policy: A Case Study of Venezuela. Cambridge: MIT Press. 1966.

García, María Pilar. 1987. La Experiencia de la Guayana Venezolana como un Polo de Dessarrollo: ¿Un Fracaso del Modelo Teórico, de la Institución Planificadora o del Estilo de Planificación? In "Guayana 25 Años Después: Teoría y Práctica de la Planificación Urbana." Cuadernos Sociedad Venezolana de Planificación. Venezuela: CILDIS, CVG, CONICIT: 17-69.

Holston, James. 1989. The Modernist City: An Anthropological Critique of Brasilia. Chicago and London: The University of Chicago Press.

Irazábal, Clara. 2000. Governance and the Practices of Urbanism: The Politics of Development in Curitiba. Presentation at Symposium "Desarrollo Regional y Urbano en la Era Global.” Bogotá, Colombia.

Izaguirre, Maritza. 1977. Ciudad Guayana y la estrategia del desarrollo planificado. Caracas: Ediciones SIAP.

Lynch, Edward. 1973. Propositions for planning new towns in Venezuela. Journal of Developing Areas, vol. 7: 549-570. 
MacDonald, John S. 1969. Migration and the population of Ciudad Guayana, in Lloyd Rodwin (ed.) Planning Urban Growth and Regional Development: the Experience of the Guayana Program in Vene₹uela. Cambridge:MIT Press: 109-125.

Marcano, Esther and John Foley. 1994. Asesoría al Plan de Desarrollo Urbano Local del Municipio Autónomo Caroní. Caracas, Instituto de Urbanismo/Insurbeca.

McGinn, Noel F. and Russell G. Davis. 1969. Build a Mill, Build a City, Build a School: Industrialization Urbanization and Education in Ciudad Guayana. Cambridge: MIT Press.

MINDUR, CVG and AL MACARONI. 1995. Plan de Ordenación Urbanistica Ciudad Guayana.

Negrón, Marco. 2000. El eje Orinoco-Apure: Una Visión Reaccionaria del Desarrollo. Revista SIC, Número Especial, mayo.

. 1999. Una Contrarrevolución Territorial. Urbana. Caracas, Maracaibo: FAU/

UCV \& IFA/LUZ. Vol.4, No. 24, Enero-Julio: 5-9.

Peattie, Lisa. 1987. Planning: Rethinking Ciudad Guayana. Ann Arbor: University of Michigan Press. $4^{\text {th }}$ ed. 1990.

1968. The View from the Barrio. Ann Arbor: University of Michigan Press.

Penfold, Anthony H. 1966. Ciudad Guayana: Planning a New City in Venezuela, Town Planning Review, 36 (4): 225-248.

Perroux, François. 1955. Note sur la notion de pôle de croissance. Economie Appliquée. 7: 307-320.

Rakowski, Cathy A. 1985. The planning process and the division of labor in a new industrial city: The case of Ciudad Guayana, Venezuela. In John Walton (ed.), Capital and Labour in the Urbanized World. London: Sage: 195-223.

Sociology, 10: 3-28.

1987. Women in Steel: The case of Cuidad Guayana, Venezuela. Qualitative

1989. Evaluating Development: Theory, ideology and planning in Ciudad Guayana, Venezuela. International Journal of Contemporary Sociology, 26: 71-92.

1991. Gender, family, and economy in a planned industrial city: The working and lower-class households of Ciudad Guayana. In Rae Lesser Blumberg (ed.), Gender, Family and Economy: The Triple Overlap. Newbury Park, CA: Sage: 149-172.

1995. Planned Development and Women's Relative Power: Steel and Forestry in Venezuela. Latin American Perspectives, 22: 51-75.

Rivière d'Arc, Hélène and Graciela Schneier. 1974. Activités informeles et l'éspace: le cas de villes nouvelles de Ciudad Guayana, Venezuela, et Camaçarí, Brésil. Tiers Monde, vol. 
15: 653-667.

Robinson, David J. 1969. The City as Center of Change in Modern Venezuela, in David Fox and David J. Robinson Cities in a Changing Latin America. London: Latin American Publications Fund: 23-48.

Rodwin, Lloyd. 1965. Ciudad Guayana: A New City, Scientific American, 23: 122-132.

(ed.). 1969. Planning Urban Growth and Regional Development: the Experience of the Guayana Program in Venezuela. Cambridge: MIT Press.

Rostow, Walter. 1960. Stages of Economic Growth: A Non-Communist Manifesto. Cambridge Mass.: MIT Press.

USGS Report on Vargas Disaster: http://pr.water.usgs.gov/public/venezuela/ [last accessed 09/15/2004]

Vila, Elisenda. 1987a. Plan de Desarrollo Urbano de Ciudad Guayana. In "Guayana 25 Años Después: Teoría y Práctica de la Planificación Urbana." Cuadernos Sociedad Venezolana de Planificación. Venezuela: CILDIS, CVG, CONICIT: 71-80.

1987b. La Organización Voluntaria del Estado: Ciudad Guyana. Revista

Colegio de Arquitectos de Venezuela, No. 53: 32-39

Voilich, Francis. 1987. Urban Planning for Latin America: the Challenge of Metropolitan Growth. Lincoln Institute: Boston.

Von Moltke, Willo. 1969. The evolution of the Linear Form, in Lloyd Rodwin (ed.), Planning Urban Growth and Regional Development: the Experience of the Guayana Program in Venezuela. Cambridge: MIT Press: 126-146.

\section{Interviews}

Césaris, María Nuria de. Urban specialist, General Coordinator of the Pueblo Guri Project. Interviewed by the author in Ciudad Guayana. August 23, 2000.

Galíndez, José. Community leader Pueblo Guri, Sector Llovizna. Interviewed by the author at the Guri relocation camps. August 23, 2000.

Giusti, Teresa. Architect at the CVG. Interviewed by the author in Ciudad Guayana. August 22, 2000.

Meier, Richard. Architect. Collaborating planner at the Joint Center during the 1960s and 1970s for the planning of Ciudad Guayana. Interviewed by the author at Berkeley. December 12, 2000.

Moreno, Elena. Social Worker at the CVG, Department of Social Development. Social Coordinator at the Guri relocation camps. Interviewed by the author at the Guri relocation camps. August 23, 2000. 
Olivieri, Pedro. Vice-President of Planning at the CVG, substituting for Yajaira Briceño. Interviewed by the author in Ciudad Guayana. August 22, 2000.

Salazar, Fanny. Architect at the CVG. Director of the Department of Urban Planning. Interviewed by the author in Ciudad Guayana. August 22, 2000. Also e-mail correspondence in 2002.

Santiago, Francisco. Economist at the CVG. Interviewed by the author. August 22, 2000.

Vila, Elisenda. Emeritus professor of the Institute of Urbanism, Central University of Venezuela. Extensive, on-going work and research experience in Ciudad Guayana. Interviewed by the author in Florence, Italy, October 20, 2000. 